\title{
ПЕДАГОГІЧНІ УМОВИ ФОРМУВАННЯ ІННОВАЦІЙНОЇ КУЛЬТУРИ МАЙБУТНЬОГО ВЧИТЕЛЯ ПОЧАТКОВОЇ ШКОЛИ В УМОВАХ РЕФОРМУВАННЯ ЗМІСТУ ОСВІТИ
}

\author{
Григорович О. П., Пахальчук Н. О.
}

\section{ВСТУП}

Інтеграція науки й виробництва зумовила пряму залежність конкурентоспроможності країни на світовому ринку від наукових досягнень i якості підготовки іiі фахівців. У загальній стратегії інноваційного розвитку країни як ніколи необхідний педагог, який швидко реагує на зміни, що відбуваються в суспільстві, мобільний, здатний брати участь в інноваційній діяльності, критично мислити, уміє орієнтуватися в нестандартних ситуаціях, прагне до безперервного особистісного та професійного вдосконалення.

У цьому контексті зростає актуальність розроблення принципово нових підходів до процесу формування інноваційної культури майбутніх учителів. До теперішнього часу для наукового вирішення проблеми формування інноваційної культури вчителя склалися особливі передумови, а саме: інноваційний рух провідних університетів світу за перебудову шкільної освіти; пошукова орієнтація зарубіжної дидактики на обгрунтування методології дослідницького підходу до навчання; створення й функціонування грантової системи в галузі розроблення прикладних досліджень шкільної практики.

Аналіз наукових джерел показує, що до теперішнього часу розроблені деякі аспекти проблеми підвищення кваліфікації педагогічних кадрів: андрагогічні моделі випереджаючого навчання, взаємодії органів управління освіти, методичних служб з інститутом підвищення кваліфікації у створенні умов для безперервного навчання вчителів, модернізації педагогічної освіти (К. Крутій, І. Дичківська, О. Бережнова, Л. Мітіна, I. Прокопенко, В. Радул, Т. Соболь, I. Назаревич, Н. Дятленко та ін.). Проблема актуалізації та реалізації інноваційного потенціалу вчителя в умовах школи розглядалася в дослідженнях В. Кравцова, М. Михайличенко, І. Бойка, В. Григора, Л. Мартинець та ін. Питання управління інноваційними процесами в системі освіти стали предметом дослідження С. Волкової, О. Касьянова, О. Мармаза, І. Бабина, Л. Василенко, І. Гришина, Р. Вдовиченко, Т. Волобуєвої, Н. Сас та ін. Хоча більшість науковців єдині в думці, що сформовані вимоги до компетентності, знань, 
соціально значущих особистісних якостей учителів змінилися, залишаються недостатньо розробленими закономірності, фактори, умови становлення та розвитку інноваційної культури майбутніх учителів, перспективні моделі їх навчання в період професійної діяльності. Актуальним залишається також питання обгрунтування педагогічних умов формування інноваційної культури майбутнього вчителя початкової школи.

Аналіз стану освітньої практики, педагогічних досліджень і наукової літератури дав змогу виявити низку протиріч між потребою системи освіти в учителях із високим рівнем інноваційної культури й фактичним його зниженням; інтересом, що зростає, педагогічної науки до проблеми підвищення інноваційної культури майбутнього вчителя i слабкою розробленістю теоретичних і практичних аспектів зазначеної проблеми; потенційними можливостями системи освіти зі створення умов формування інноваційної культури майбутнього педагога на основі компетентнісного підходу і традиційною системою навчання.

\section{1. Інноваційна культура вчителя початкової школи як педагогічний феномен}

Українське суспільство нині перебуває в стані динамічного розвитку, характерна особливість якого - інноваційні зміни в усіх сферах життєдіяльності. Як відзначають К. Слізарова, Л. Холодкова, В. Чорноліс ${ }^{1}$, перехід від «матеріальної» до «інтелектуальної» економіки вимагає ліквідації відставання інноваційних процесів в організації, управлінні, освіті від досягнень наукової й технічної думки, зумовлює необхідність формування інноваційної культури особистості та суспільства загалом. Як бачимо, потенціал розвитку українського суспільства на постіндустріальному етапі мірою, що все зростає, визначається масштабами участі громадян в інноваційних перетвореннях. А це, як зазначає О. Новікова ${ }^{2}$, прямо залежить від рівня людського капіталу. Учений один із перших у сучасній педагогіці порушив проблеми радикальної перебудови цілей, змісту, форм, методів і засобів організації навчання відповідно до вимог нового часу. О. Новікова підкреслює, що постіндустріальна епоха потребує нових освітніх інститутів. На зміну традиційному приходить розуміння освіти

1 Елизарова Л.Е., Холодкова Л.А., Чернолес В.П. Инновационная культура личности и общества: сущность и условия формирования. Инноващии в образовании. 2006. № 3. C. 74-83.

${ }^{2}$ Новикова Е.П. Ориентация на гуманистические традиции и ценности как идеология инновационных образовательных процессов. Сибирский педагогический журнал. 2006. № 5. С. 130. 
як надбання особистості, як засоби iï самореалізації, побудови особистої кар'єри.

Аналогічної точки зору дотримується Л. Хоружа ${ }^{3}$, відзначаючи, що ключовим фактором успішного розвитку суспільства й економіки, заснованої на знаннях, є активізація «людського капіталу» шляхом колективного підвищення рівня освіти (багаторівневого, багатофункціонального). Фундаментальні зміни в суспільстві цілком закономірно вимагають іншої освіти - постіндустріальної; нового типу вчителя - не носія готового знання, а вчителя-професіонала, здатного працювати в нових умовах. Учителю необхідно не тільки володіти високим рівнем загальної професійної культури, а й брати участь в інноваційній діяльності, нетрадиційно підходити до розгляду різних ситуацій, організовувати свою діяльність на творчій, а якщо вимагає ситуація, і на інноваційній основі.

Термін «інноваційна культура вчителя» в педагогічній літературі ще порівняно недавно не зустрічався. Однак по мірі вступу суспільства «в новий етап цивілізації, на якому рушійною силою $є$ цінності, створені знаннями», відбувається поступовий перехід від працівника «вузької спеціалізації» до працівника «широкого діапазону», здатного здійснювати оцінку, творчий синтез інформації, проникати в сутність проблеми, здійснювати коригування колишніх цінностей ${ }^{4}$. У цьому контексті широке використання в педагогіці поняття «інноваційна культура вчителя» $є$ наслідком об'єктивних процесів, що відбуваються у сфері освіти інноваційного сучасного суспільства: Driven Society. Цілком закономірно, що особливої значущості набуває проблема якісно нового рівня підготовки педагогічних кадрів. На нашу думку, проблема формування та розвитку в майбутнього вчителя інноваційної культури - це напрям розвитку знань, пов'язаний із глобальною проблемою ефективності використання людських ресурсів.

У зв'язку зі все більш активним обговоренням проблеми підвищення інноваційної культури майбутнього вчителя на різних рівнях освіти зростає потреба в теоретико-методологічному аналізі наявних підходів до розкриття сутності досліджуваного поняття «інноваційна культура вчителя початкової школи». Необхідність такого аналізу зумовлена тим, що досліджуване поняття ще знаходиться в процесі свого становлення й педагогічна думка вкладає в нього

3 Хоружа Л.Л. Компетентнісний підхід в освіті: ретроспективний погляд на розвиток ідеї. Педагогічна освіта: теорія $і$ практика. Психологія. Педагогіка : збірник наукових праць. Київ : КМПУ імені Б.Д. Грінченка, 2007. С. 178-183.

4 Дичківська I.M. Інноваційні педагогічні технології : навчальний посібник. Київ : Академвидав, 2004. 352 с. 
досить широкий спектр змісту - від практико-житейського до абстрактно-філософського, що призводить до використання одного й того ж поняття в різних сенсах. У цьому контексті видається доцільним розібратися в науковому змісті досліджуваного поняття.

Система освіти в усі часи впливала й впливає на соціальноекономічний прогрес суспільства. Основними тенденціями розвитку вітчизняної освіти у XXI столітті стали глобалізація, що зростає, необхідність включення українського суспільства в загальносвітові процеси, пошук моделей освіченої людини, інституціоналізація нового ключового принципу освіти «навчання протягом усього життя». Стрімкий технічний прогрес актуалізує проблему формування й розвитку в майбутніх учителів культури, що виявляється в готовності і здатності особистості брати участь в інноваціях, сприяти їм, у крайньому випадку, не протидіяти реалізації нововведення 3 прогнозованим позитивним ефектом. Відмінною особливістю системних змін початкової ланки освіти є те, що їі нова якість сьогодні «вирощується» в самих закладах, безпосередньо в ході локальних інновацій, з використанням такого важливого ресурсу, як потенціал самостійної продуктивної діяльності окремих учителів і цілих колективів. Як бачимо, значущість проблеми інноваційної культури вчителя початкової школи визначається самим життям, орієнтацією суспільства на інноваційний розвиток системи початкової освіти.

В. Самохін, В. Чорноліс інноваційну культуру людини вважають галуззю духовного життя, що відображає «ії ціннісну орієнтацію, закріплену в мотивах, знаннях, уміннях, навичках, в образах і нормах поведінки й забезпечує сприйнятливість їм нових ідей, готовність і здатність до підтримки та реалізації нововведень у всіх сферах життя» ${ }^{5}$. Досліджуваний феномен використовується в науковій літературі у двох значеннях: вузькому й широкому. У вузькому сенсі щоб підкреслити, що зараз недостатньо говорити просто про знання, навички, уміння, необхідні для інноваційної діяльності.

Л. Єлізарова, Л. Холодкова й $\mathrm{B}$. Чорноліс ${ }^{6}$ роблять спробу осмислення поняття «інноваційна культура». Цей термін розглядається ними як комплексний соціальний феномен, органічно поєднує питання науки, освіти, культури із соціальної й насамперед із професійною

5 Самохин В.Ф., Чернолес В.П. Педагогические инновации в системе профессионального образования: цели и сущность. Инновации в образовании. 2006. № 6. С. 4-9.

${ }^{6}$ Елизарова Л.Е., Холодкова Л.А., Чернолес В.П. Инновационная культура личности и общества: сущность и условия формирования. Инноващии в образовании. 2006. № 3. C. 74-83. 
практикою в різних сферах спільноти: управлінні, економіці, освіті, культурі.

Поняття «інноваційна культура вчителя початкової школи» синтезується з поняттям «інноваційна педагогічна діяльність». У низці наукових робіт містяться підходи до формування поняття «інноваційна діяльність». У колективній монографії «Інноваційна педагогічна діяльність: історія, теорія, практика» (1999) визначається дата введення поняття «інноваційна діяльність» у науковий обіг - це 70-ті роки $\mathrm{XX}$ століття. Спочатку поняття використовувалося в економіці, а потім і в інших сферах науки.

Наприклад, К. Крутій ${ }^{7}$ розкриває сутність та особливості інноваційної діяльності в ДНЗ, аналізує підходи до організації науково-методичної роботи в умовах інноваційних перетворень. Дослідниця українського дошкілля зазначає, що на рівні дошкільного навчального закладу інноваційна діяльність передбачає цілеспрямований процес застосування інновацій (зміни всередині системи) та експериментальної перевірки результативності й можливостей використання інновацій в інших дошкільних навчальних закладах. При цьому результатом інноваційної діяльності дошкільного навчального закладу є або інноваційний продукт (результат науково-дослідницької розробки), або інноваційна продукція нові конкурентоздатні освітні послуги.

Однією з особливостей сучасної педагогічної науки є ії інноваційний характер, відкритість, здатність до оновлення. На думку І. Дичківської інновації в педагогіці пов'язані із загальними процесами в суспільстві. В. Лазарєв, Б. Мартиросян ${ }^{9}$ інноваційну діяльність учителя розглядають як процес цілеспрямованого перетворення практики освітньої діяльності за рахунок створення, розповсюдження та освоєння нових освітніх систем або їх компонентів. На нашу думку, для інноваційної педагогічної діяльності характерний особливий стиль, що включає й стиль управлінської діяльності, і стиль саморегуляції, і стиль спілкування, когнітивний стиль її суб'єкта - учителя, автора. Важливою особливістю інноваційної діяльності $\epsilon$ високий рівень іiі прояву - педагогічна майстерність, яка дає змогу успішно вирішувати професійні завдання. Ми погоджуємося 3 думкою науковців, які схильні вважати, що інноваційна діяльність у сфері освіти являє собою складну систему діяльності

7 Крутій К.Л. Інноваційна діяльність у сучасному ДНЗ: методичний аспект. Дошкільне виховання. 2007. № 5. С. 5-7.

8 Дичківська I.M. Інноваційні педагогічні технології : навчальний посібник. Київ : Академвидав, 2004. 352 с.

9 Лазарев В.С., Мартиросян Б.П. Нормативный поход к оценке инновационной деятельности школы. Педагогика. 2003. № 3. С. 17-26. 
колективного характеру, що передбачає послідовне включення безлічі суб'єктів у перетворювальні процеси.

Учені виділяють найбільш характерні ознаки інноваційної діяльності:

- якісний тип перетворень, що характеризується наявністю соціально значущого нововведення системного типу;

- система діяльностей, тобто наявність декількох взаємозумовлених і взаємопов'язаних цілей, процесів і суб'єктів діяльності (колективна діяльність);

- практико-орієнтованість, тобто спрямованість на вирішення актуальних проблем практики в зоні їі найближчого розвитку;

- рефлексивний супровід усіх етапів інноваційної діяльності;

- можливість використання отриманого результату як засобу діяльності;

- застосування нових засобів здійснення діяльності й поява в суб’єктів діяльності нових здібностей.

Варто зазначити, що в останне десятиліття $\mathrm{XX}$ століття вдосконалюється нормативно-правова база інноваційної діяльності, визначаються відповідні пріоритетні напрями державної політики України. Оцінювання стану інноваційної сфери в Україні, визначення найбільш актуальних проблем і бар'єрів, що гальмують інноваційну діяльність, а також в обгрунтування стратегічних напрямів інноваційного розвитку держави та розроблення конкретних пропозицій щодо його стимулювання в умовах подальшої інтеграції України у світовий економічний i науково-технологічний простір містяться в Національній доповіді «Інноваційна Україна - 2020».

Розглянемо підходи вчених до розкриття змісту поняття «педагогінноватор». У педагогічній літературі відомі три категорії керівників: педагог-новатор, педагог-модернізатор, педагог-інноватор (В. Загвязинський). Згідно із цією класифікацією педагог-новатор - це автор нової педагогічної системи як сукупності взаємопов'язаних ідей і відповідних технологій (Ш. Амонашвілі, А. Макаренко, В. Сухомлинський, С. Шацький та ін.); педагог-модернізатор - творчо працюючий, займається інноваційною діяльністю, у процесі якої, не створюючи нового, уводить нові елементи або вдосконалює елементи чинної системи, по-новому їх комбінує; педагог-інноватор - швидко сприймає й уміло використовує традиційні та нові підходи й методи.

Погоджуємося $з$ точкою зору Н. Юсуфбекової, яка по-різному трактує поняття «вчитель-новатор» і «вчитель-інноватор». На ії думку, учитель-новатор - це найчастіше вчитель, що втілює в життя ідеї творчо працюючих колег, а вчитель-інноватор - це вчитель, який 
створює й реалізує нове у змісті та в процесі навчання й виховання. Отже, інноваційну діяльність педагога можна визначити як таку, що:

- грунтується на принципах особистісного підходу, тобто має гуманістичну центрацію, спрямованість на особистість;

- має творчий характер;

- формою її організації є дослідно-експериментальна робота;

- має струнку мотивованість на пошук нового в цільових, змістових і професійних характеристиках навчально-виховного процесу.

Розглянуті вище поняття «інноваційна діяльність», «педагогінноватор», «інноваційна педагогічна діяльність» співвідносяться 3 домінантним поняттям дослідження «інноваційна культура вчителя» як часткове із загальним. При цьому виявляється прямо пропорційна залежність: чим вища інноваційна культура вчителя, тим більш ефективна інноваційна діяльність, тим більш вагомі й значущі результати професійної діяльності вчителя-інноватора, інноваційної педагогічної діяльності, так і навчального закладу загалом.

У сучасному освітньому просторі склалася парадигмальна множинність педагогічної реальності. Вона проявляється, 3 одного боку, у становленні в педагогічній практиці інноваційних видів і типів навчальних закладів, що відрізняються від масової загальноосвітньої школи за цільовим, змістовим і процесуальним характеристиками освіти. 3 іншого боку, у педагогічній науці йде процес інтелектуального формування безлічі концепцій особистісноорієнтованої освіти як основи гуманістичної парадигми освіти. За останні роки інноваційна освітня діяльність набула системного характеру. Її відрізняють:

1) гуманістична спрямованість системи освіти, яка змінює характер взаємин між учителем і дитиною;

2) активне проникнення в початкову освіту результатів новітніх психолого-педагогічних досліджень і їх оперативне використання;

3) зміна уявлень про особистість, яка, крім соціальних якостей, наділяється різними суб'єктивними властивостями, що характеризують iï автономію, незалежність, здатність до вибору, рефлексії, у зв’язку 3 чим змінюється піi роль у педагогічному процесі - вона стає його системотвірним началом;

4) ревізія, що відбувається, ставлення до вчителя як об’єкта педагогічних впливів та остаточне закріплення за ним статусу суб'єкта початкової освіти й власного життя.

У свою чергу, інноваційна діяльність формує освітній інноваційний простір, у якому затребуваний не вчитель із застарілим багажем знань, орієнтований лише на традиційні методи навчання та форми діяльності, a творчо мислячий педагог. Як правильно зазначає О. Новікова, 
«у зрілого вчителя викликає інтерес і сам інноваційний процес, і відчуття себе в просторі цієї діяльності» ${ }^{10}$.

Інноваційні перетворення, зміна змісту освіти, активне вбудовування в освітній простір нових інноваційних технологій ніколи не вийде на етап практичної реалізації поза педагогом, його розумінням сутності перетворень і прийняття ідей сучасної освіти. Усе це породжує потребу у формуванні в учителя початкової школи інноваційної культури.

\section{2. Стан сформованості інноваційної культури вчителя початкової школи}

3 метою підтвердження об'єктивності висунутих теоретичних положень, а також виявлення рівня сформованості інноваційної культури вчителів ми звернулися до розроблення та апробації комплексу діагностичних методик, що являють собою систему дослідницьких прийомів. Діагностичний комплекс включав у себе спостереження, бесіди, анкетування, опитувальні методики, тести, діагностичні карти, аналіз продуктів педагогічної діяльності.

У дослідженні ми обгрунтували такі критерії, що характеризують рівні сформованості інноваційної культури вчителів початкової школи: відповідальне ставлення до роботи; професійний саморозвиток, а також показники: сприйнятливість до нових ідей; творча продуктивність.

Для визначення вихідного рівня інноваційної культури вчителів на констатуючому етапі експерименту проведено опитування. Із цією метою розроблені анкети «Оцінювання стану інноваційної діяльності в системі початкової освіти», «Ставлення до педагогічних інновацій». Вибірку дослідження становили відповіді 21 вчителя-практика. 3 метою діагностики ставлення сучасного учителя до роботи його сприйнятливості до нових ідей, творчої продуктивності нами розроблено анкету, яка містила 10 питань, об'єднаних спільною темою: «Як Ви оцінюєте стан інноваційної діяльності в системі початкової освіти району, міста?», «Які 3 перерахованих нижче педагогічних нововведень $\epsilon$ найбільш поширеними?», «Які 3 перерахованих управлінських нововведень $\epsilon$ найбільш поширеними у Вашому навчальному закладі?», «Які з перелічених форм і методів поширення досвіду, на Ваш погляд, є найбільш ефективними?», «Звідки дізнаєтесь інформацію про нововведення?» тощо.

Загалом дослідження показало, що більшість опитаних (82\%) позитивно ставляться до діяльності установ, які впроваджують

${ }^{10}$ Новикова Е.П. Ориентация на гуманистические традиции и ценности как идеология инновационных образовательных процессов. Сибирский педагогический журнал. 2006. № 5. С. 130. 
інноваційні програми; $63 \%$ респондентів самі $\epsilon$ ініціаторами нововведень, інноваційних ідей; 92\% учасників опитування позитивно оцінюють державну політику в галузі освіти, інновацій. Водночас дослідження дало змогу виявити негативні тенденції, що характеризують інноваційні процеси. Наприклад, оцінка результатів освоєння педагогічних інновацій у вищому навчальному закладі виявилася майже в два рази вища, ніж на курсах підвищення кваліфікації (рис. 1).

Отже, аналіз результатів експериментального дослідження дає можливість зробити висновок про недостатню ефективність курсів підвищення кваліфікації, які не відповідають очікуванням учителів суб'єктів освітнього процесу.

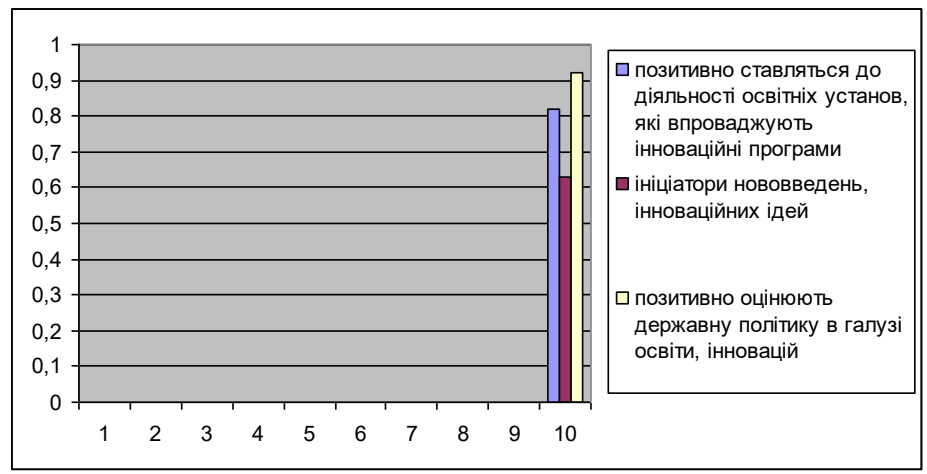

Рис. 1. Оцінка ставлення вчителів-практиків до інновацій

Проведене дослідження дало можливість провести не тільки аналіз стану перспектив розвитку системи освіти, а й визначити ставлення учителів до інноваційних процесів. Ці дані стали вихідними для проведення експерименту.

3 метою визначення рівнів сформованості провідних функцій інноваційної культури учителя початкової школи (гносеологічна, організуюча, перетворювально-творча) на формувальному етапі експерименту ми використовували можливості кваліметричного інструментарію, за визначенням В. Беспалько, $\epsilon$ способом виявлення діагностичної якості особистості. Відповідно до кваліметричного підходу, досліджувана якість розглядається як ієрархічна сукупність властивостей, яка будується так, що властивості рівня, позначеного як і, визначаються властивостями, відповідними $(\mathrm{i}+1)$ рівня $(\mathrm{i}=0,1,2 \ldots$, е.). 
У контексті дослідження діагностичні компоненти й рівні сформованості, що становлять складові ознаки (функції), сукупність яких і становить досліджуване якість позначені на рис. 2.

Метою констатувального етапу експерименту було дослідження, як зазначалося вище, рівня сформованості провідних функцій інноваційної культури учителів. Для реалізації завдань цього етапу використовувалася анкета «Інноваційна культура вчителя початкової школи».

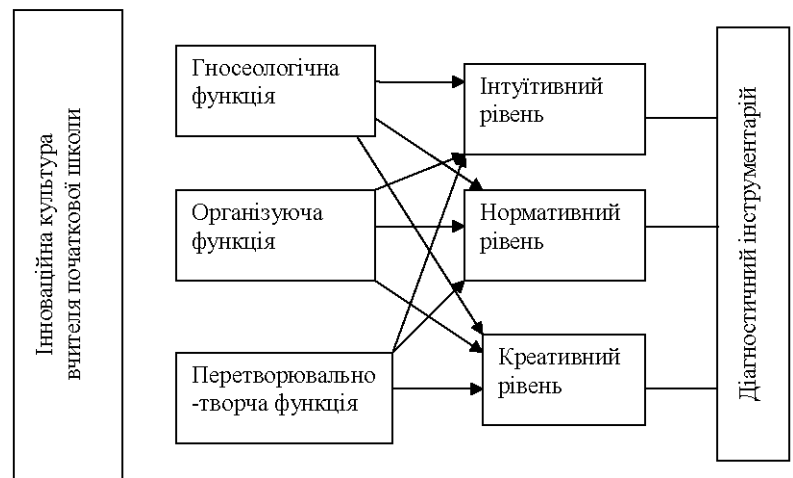

\section{Рис. 2. Кваліметричне дослідження рівнів сформованості інноваційної культури вчителя початкової школи}

Предмет вивчення становлять оціночні характеристики інноваційної культури вчителя як основних суб'єктів системи загальної освіти в сучасній освітній ситуації. У ході дослідження передбачалося вирішення таких основних завдань:

- визначити ставлення вчителів до необхідності розвитку інноваційних процесів у початковій ланці освіти;

- виявити пріоритетні функції вдосконалення та розвитку інноваційної культури вчителя, фактори, що впливають на рівень іiі сформованості;

- визначити стан інноваційної діяльності в системі початкової освіти;

- визначити найбільш перспективні форми й методи трансляції інноваційного досвіду в системі підвищення кваліфікації вчителів початкової школи;

- представити прогностичну оцінку розвитку інноваційної культури вчителя початкової школи. 
В анкету «Інноваційна культура вчителя початкової школи» включені такі питання: «Чим обгрунтована, на Ваш погляд, необхідність оволодіння вчителем інноваційною культурою?», «Які знання, на Ваш погляд, необхідно включити в зміст інноваційної культури вчителя початкової школи?», «Які показники, на Ваш погляд, важливі під час визначення ступеня сформованості інноваційної культури вчителя початкової школи?», «Яка система трансляції інноваційного досвіду існує у Вашому районі?», «Як Ви оцінюєте стан інноваційної діяльності в системі початкової освіти Вашого району?», «Що, на вашу думку, необхідно зробити на рівні району для підвищення інноваційної культури вчителів?» тощо.

Аналіз відповідей респондентів на перше запитання дав змогу виділити три групи учителів: практики (46\%), фасилітатори (29\%) і творці (25\%) (рис. 3).

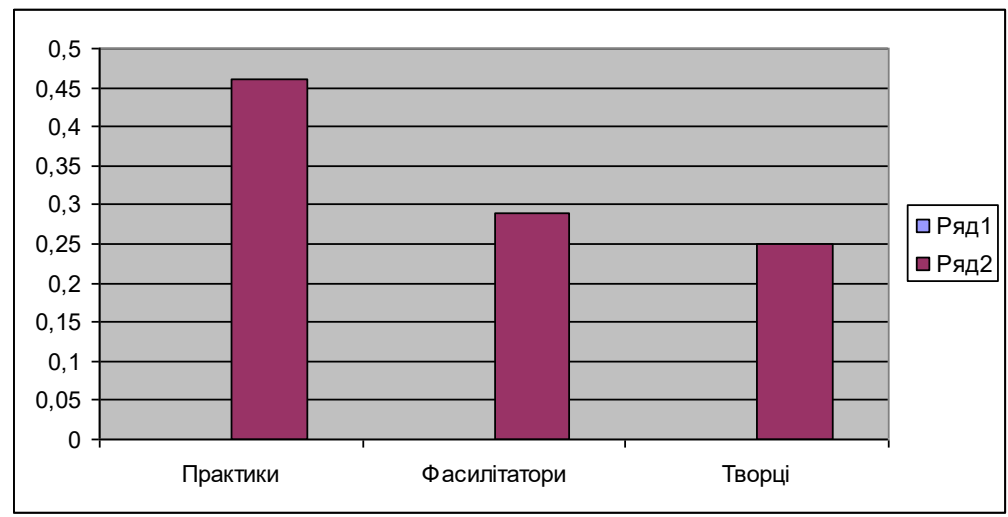

\section{Рис. 3. Ставлення трьох груп учителів до оволодіння інноваційною культурою}

Як бачимо, більшість опитаних увійшли до групи практиків, далі йдуть фасилітатори, лише на третій позиції - творці. Учителі, які належать до першого типу (практики), розглядають інноваційну культуру як необхідну умову виживання в професійній діяльності. У респондентів-фасилітаторів чітко виражена споглядальнорефлексивна спрямованість. Вони ще не визначилися в тому, яких результатів хочуть домогтися, до чого необхідно прагнути. Тим не менше вони позитивно налаштовані на процес підвищення інноваційної культури. Педагоги цього рівня тривожні, їх хвилюють справжні 
(поточні) проблеми, а не перспективи майбутнього. Погіршує ситуацію соціальна нестабільність сучасного суспільства.

Творці сенс інноваційної культури бачать у прагненні не зупинятися на досягнутому рівні професіоналізму, у підвищенні мотивації до реалізації нових освітніх завдань. Якщо сучасне суспільство - це суспільство знань, то лідером у такому суспільстві є особистість, здатна формувати, інтегрувати, поширювати нові знання. Така особистість не тільки пристосовується до ринку, а й сама його формує.

Серед факторів, що позитивно впливають на рівень інноваційної культури вчителів, респонденти всіх трьох типів виділяють такі: поява різноманітних освітніх програм, навчальних планів, варіативних підручників, методик і технологій виховання й навчання; підвищення вимог до якості дослідно-експериментальної роботи; включення в систему атестаційних показників педагогічних працівників дослідницького параметра (розроблення авторської освітньої програми, проведення власного наукового дослідження тощо).

Респонденти виділяють як досить розвинену в себе гносеологічну функцію (50\%), реалізація якої дає змогу освоювати систему нових знань. Ця функція передбачає вдосконалення таких гносеологічних умінь, як уміння екстраполювати отримані знання на педагогічну діяльність, здатність створювати умови для ефективного розвитку й саморозвитку особистості учнів 3 використанням філософських, психологічних і педагогічних знань, власного практичного досвіду та інтуїції. На другій позиції в респондентів знаходиться організуюча функція (22\%), що виявляється в умінні педагогів коректно застосовувати на практиці заходи науково-педагогічного дослідження, здатність здійснювати спостереження й самоспостереження за зовнішньою i внутрішньою реальністю. Перетворювально-творчу функцію як слаборозвинену відзначили $18 \%$ респондентів. Найбільші труднощі в респондентів викликають такі вміння, як здатність приймати рішення щодо впровадження нових ідей, створювати програми власної діяльності. Недостатньо розвиненими $є$ й інші функції: консолідуюча й морально-етична (10\%).

Аналіз відповідей респондентів щодо особистісно-професійного зростання в аспекті інноваційної культури виявив таке: учителі відчувають внутрішню потребу в особистісному й професійному зростанні. Про це свідчить їхнє відчуття недостатності своєї загальної та професійної компетентності (криза некомпетентності); педагоги визнають перспективними поряд із традиційними курсами підвищення кваліфікації такі форми, як виїзні заняття на базі інноваційних шкіл, майстер-класи, педагогічні майстерні, стажування. Про це свідчить досить висока розвиненість організаторських, комунікативних умінь; 
спрямованість на творчість у професійній та особистісній реалізації, висока потреба в пізнанні; прагнення до самореалізації в учителів нижче середнього рівня. Це зумовлює нерозвиненість у них проектувальних умінь, а також умінь ранжувати цілі, рефлексувати; основна проблема, 3 якою учителі пов'язують свої труднощі в інноваційній діяльності, - недостатне матеріально-технічне забезпечення та слабке фінансування навчальних закладів, що тягне за собою неможливість реалізувати деякі інновації та ідеї.

Серед характеристик інноваційної культури респонденти вибудували таку ієрархію: 1) високий професіоналізм; 2) соціальна активність; 3) самовдосконалення, самоосвіта; 4) професійна захопленість; 5) пізнавальна потреба; 6) гнучкість поведінки; 7) інтерес до нових ідей, підходів.

Загалом інноваційна культура розглядається як багатоаспектне поняття. По-перше, вона розуміється як стратегічний ресурс нового століття. По-друге, інноваційна культура забезпечує сприйнятливість людей до нових ідей, їх готовність і здібність підтримувати й реалізувати інновації в усіх сферах життя. По-третє, інноваційна культура відображає ціннісну орієнтацію людини, закріплену в мотивах, знаннях, уміннях і навичках, а також в образі й нормах поведінки.

Формування інноваційної культури пов'язане з розвитком творчих здібностей і реалізацією креативного потенціалу самої людини іiї суб'єкта. Інноваційна культура віддзеркалює цілісну орієнтацію людини, закріплену в мотивах, знаннях, вміннях і навичках, а також в образах i нормах поведінки. Формування інноваційної культури грунтується на системі цінностей суспільства, які являють собою низку ідей, часто неписаних, які обгрунтовують цілі суспільства.

Існують різні підходи до розуміння феномена «інноваційна культура вчителя початкової школи». У рамках першого системного підходу вона розглядається як результат оволодіння педагогом апаратом інноваційної діяльності, спрямованої в кінцевому підсумку на перетворення конкретної педагогічної ситуації (В. Краєвський, О. Новіков, А. Саранов та ін.).

У контексті системного підходу інноваційна культура вчителя початкової школи є одним із найважливіших функціонально значущих елементів культури суспільства загалом. Представники іншої точки зору (В. Лазарєв, В. Слободчиков) інноваційну культуру вчителя визначають як особливу форму функціонування педагогічної свідомості, що керує мисленням людини, що виявляється в усвідомленні педагогом мотивації до інноваційної діяльності. 
Прихильники третього підходу (О. Бондаревська й ін. $)^{11}$ розглядають інноваційну культуру як особливу форму загальнолюдської культури, що зароджується в найрізноманітніших соціокультурних умовах. Учені виходять із того, що процес формування інноваційної культури майбутнього вчителя здійснюється в «культуровідповідному освітньому середовищі, усі компоненти якої наповнені сенсами і слугують людині, яка вільно проявляє свою індивідуальність, здатна до культурного саморозвитку й самовизначення у світі культурних цінностей». Л. Слізарова ${ }^{12}$ виділяє низка педагогічних якостей, що дають змогу судити про рівень інноваційної культури вчителя: висока загальна культура, що дає можливість орієнтуватися в житті; ерудованість, яка дає можливість вільно мислити, знаходити і пропонувати оптимальні рішення в нестандартних ситуаціях; нестандартність інтелекту: незвичайність сприйняття світу, своєрідний стиль педагогічної праці, розвиток творчого мислення, спостережливість; спрямованість мислення на пошук вирішення складних методичних або технологічних проблем; потреба в безперервному якісному оновленні навчально-виховного процесу; інтерес до нових ідей і підходів, до передового педагогічного досвіду й прагнення максимально реалізувати їх у своїй праці. Необхідність формування інноваційної культури вчителя підтверджується тією обставиною, що не тільки лідери, а й значна частина керівників прагнуть не до часткових нововведень косметичного характеру, а до глибинного оновлення змісту навчання й виховання та досягнення якісних результатів.

\section{3. Педагогічні умови формування інноваційної культури вчителя початкової школи}

Спираючись на вищевикладені положення про інноваційну культуру вчителя, ми вважаємо, що процес іiі формування буде протікати найкращим чином за дотримання таких педагогічних умов:

- створення оптимального інноваційного простору в установі професійної освіти для реалізації особистісної потреби керівників у пізнанні специфічних особливостей інноваційної діяльності й саморозвитку;

11 Бондаревская Е.В. Актуальные проблемы и направление инновационной деятельности в личностно-ориентированном образовательном пространстве. Воспитание как встреча с личностью. Избранные педагогические сочинения : в 2 т. Ростов-на-Дону : Издательство РГПУ, 2006. Т. ІІ. С. 307-335.

12 Елизарова Л.Е., Холодкова Л.А., Чернолес В.П. Инновационная культура личности и общества: сущность и условия формирования. Инновации в образовании. 2006. № 3. C. 74-83. 
- проектування моделі формування інноваційної культури керівника закладу дошкільної освіти на етапі професійної діяльності й технологій іiі реалізації в освітньому процесі;

- розроблення та апробація програмно-методичного комплексу й експериментальна перевірка його ефективності;

- проведення діагностики та моніторингу рівнів сформованих провідних функцій інноваційної культури керівників на всіх етапах експерименту, відстеження динаміки змін професійного зростання в досліджуваному напрямі.

Отже, на сучасному етапі постіндустріальної освіти інноваційна культура розглядається як якісна характеристика професійної діяльності вчителя, заснована на розумінні визначальної ролі інновацій у сучасному суспільстві. Формування й розвиток інноваційної культури вчителя відбувається за взаємодії як із загальними факторами, так i з факторами приватними, пов'язаними 3 конкретним напрямом діяльності.

Формування інноваційної культури пов'язане з розвитком творчих здібностей і реалізацією креативного потенціалу самої людини - iї суб'єкта. Інноваційна культура віддзеркалює цілісну орієнтацію людини, закріплену в мотивах, знаннях, уміннях і навичках, а також в образах i нормах поведінки. Формування інноваційної культури грунтується на системі цінностей суспільства, які являють собою низку ідей, часто неписаних, які обгрунтовують цілі суспільства.

\section{ВИСНОВКИ}

Резюмуючи вищевикладене, ми доходимо таких висновків. Під впливом змін, які відбулися в суспільно-політичному житті нашої країни, монополія системи освіти поступово втрачається й виявляється нездатною задовольняти нові потреби людини та суспільства. 3 урахуванням цього в нових умовах іде пошук ефективних моделей, засобів і технологій навчання вчителів, які відповідали б зміненим суспільним умовам.

У розглянутому контексті змінився підхід до визначення ролі початкової ланки освіти в розвитку інноваційної діяльності. Результати інноваційної діяльності педагогів прямо залежать від низки факторів, серед яких - організаційні соціальні, економічні, кадрові. 3 огляду на те що традиційна базова педагогічна освіта не може забезпечити вчителя на все життя знаннями, необхідними йому для ефективного виконання не лише функціональних обов'язків, а й активної участі в інноваційній діяльності, необхідно здійснення діяльності щодо формування інноваційної культури.

Представлений аналіз теоретичного матеріалу 3 досліджуваної проблеми дає змогу стверджувати, що функціонування й розвиток 
перспективних моделей навчання педагогів-інноваторів пов'язані 3 вирішенням проблем за такими напрямами, як забезпечення випереджального характеру освіти, ऑiі націленість на проблеми постіндустріального суспільства знань та інтелекту, розвиток людського капіталу; зміна змісту курсів підвищення кваліфікації з їх орієнтацією на андрагогічні технології навчання й розвиток суб'єктсуб'єктних взаємин викладача й учня; активне впровадження дистанційних моделей у навчальному процесі для підготовки вчителів до здійснення компетентної інноваційної діяльності; урахування регіональних особливостей в обгрунтуванні освітніх систем 3 орієнтацією на формування й розвиток у педагогів інноваційної культури тощо.

\section{АНОТАЦІЯ}

Проблема формування інноваційної культури вчителя початкової школи сьогодні є однією з актуальних в освітньому менеджменті. У статті обгрунтовано іiї соціально-економічну, політичну, економічну, соціокультурну зумовленість і зв'язок із випереджальним характером розвитку всіх рівнів освіти. Особливу увагу приділено визначенню сутності, змісту, компонентів феномена інноваційної культури вчителя початкової школи. Інноваційну культуру вчителя початкової ланки освіти визначено як сукупність інноваційного мислення, інноваційного розвитку та інноваційної діяльності, що визначає новий елемент професійної культури. Доведено, що початковим теоретичним базисом інноваційної культури $€$ закономірності освітньої інноватики (педагогічні, економічні, організаційно-управлінські, соціальні, політичні). У рамках теоретичного аналізу проблеми розглянуті поняття «інноваційна діяльність», «інноваційна педагогічна діяльність», «педагог-інноватор». Констатовано, що ці поняття стикаються 3 домінантним поняттям дослідження «інноваційна культура», абстрагують і синтезують його.

\section{ЛІТЕРАТУРА}

1. Анисимов Н.М. Современные представления об изобретательской и инновационной деятельности. Школьные технологии. 1998. № 5. С. 49-75.

2. Бондаревская Е.В. Актуальные проблемы и направление инновационной деятельности в личностно-ориентированном образовательном пространстве. Воспитание как встреча с личностью. Избранные педагогические сочинения : в 2 т. Ростов-на-Дону : Издательство РГПУ, 2006. Т. II. С. 307-335.

3. Дичківська I.М. Інноваційні педагогічні технології : навчальний посібник. Київ : Академвидав, 2004. 352 с. 
4. Елизарова Л.Е., Холодкова Л.А., Чернолес В.П. Инновационная культура личности и общества: сущность и условия формирования. Инновации в образовании. 2006. № 3. С. 74-83.

5. Інноваційна діяльність педагога: від теорії до успіху : інформаційно-методичний збірник / упорядник Г.О. Сиротенко. Полтава : ПОІППО, 2006. 124 с.

6. Крутій К.Л. Інноваційна діяльність у сучасному ДНЗ: методичний аспект. Дошкільне виховання. 2007. № 5. С. 5-7.

7. Лазарев В.С., Мартиросян Б.П. Нормативный поход к оценке инновационной деятельности школы. Педагогика. 2003. № 3. С. 17-26.

8. Миленкова Р.В. Інноваційна культура: новий підхід до розвитку сучасної особистості, школи, суспільства. Педагогічні науки. 2008. C. $133-142$.

9. Николаев А.И. Инновационное развитие и инновационная культура. URL: http://www.cem.erinno.ru/ru/materials/librarv/04-4.

10. Новикова Е.П. Ориентация на гуманистические традиции и ценности как идеология инновационных образовательных процессов. Сибирский педагогический журнал. 2006. № 5. С. 130.

11. Самохин В.Ф., Чернолес В.П. Педагогические инновации в системе профессионального образования: цели и сущность. Инновации в образовании. 2006. № 6. С. 4-9.

12. Хоружа Л.Л. Компетентнісний підхід в освіті: ретроспективний погляд на розвиток ідеї. Педагогічна освіта: теорія $i$ практика. Психологія. Педагогіка : збірник наукових праць. Київ : КМПУ імені Б.Д. Грінченка, 2007. С. 178-183.

\section{Information about the authors:} Hryhorovych O. P., Candidate of Pedagogic Sciences (Ph. D.), Associate Professor at the Department of Preschool and Primary Education Vinnytsia Mykhailo Kotsiubynskyi State Pedagogical University 32, Ostrozkoho Str., Vinnytsia, Ukraine

Pakhalchuk N. O., Candidate of Pedagogic Sciences (Ph. D.), Associate Professor at the Department of Preschool and Primary Education Vinnytsia Mykhailo Kotsiubynskyi State Pedagogical University 32, Ostrozkoho Str., Vinnytsia, Ukraine 